\title{
New species of Meleagros and Tarsagonum (Coleoptera: Carabidae: Platynini) from the Oriental region
}

\author{
Новые виды Meleagros и Tarsagonum \\ (Coleoptera: Carabidae: Platynini) из Ориентальной области
}

\author{
D.N. Fedorenko \\ A.H. Федоренко
}

\begin{abstract}
A.N. Severtsov Institute of ecology and evolution, Leninsky pr. 33, Moscow 119071, Russia. E-mail: dmitri-fedorenko@yandex.ru Институт проблем экологии и эволюции им. А.Н. Северцова, Российская Академия Наук, Ленинский пр-т 33, Москва 119071, Россия.
\end{abstract}

KEY WORDS: Coleoptera, Carabidae, Platynini, Meleagros, Tarsagonum, new subgenus, new species, new synonym, Vietnam, Oriental region.

КЛЮЧЕВЫЕ СЛОВА: Coleoptera, Carabidae, Meleagros, Tarsagonum, новый вид, новый подрод, новый синоним, Вьетнам, Ориентальная область.

ABSTRACT. Six new species, Meleagros laticeps sp.n., M. astericollis sp.n., M. setulosus sp.n., and $M$. pseudosinicola sp.n., from Vietnam, Tarsagonum breve sp. n. from Laos and T. indicum sp.n. from India, are described. A new subgenus, Louwerensium subg.n., is erected for the two described species of Tarsagonum and T. kaszabi Louwerens, 1966. New synonymy is established: Loxocrepis Eschscholtz, $1829=$ Violagonum Darlington, 1956, syn.n.

РЕЗЮМЕ. Описаны 6 новых видов жужелиц: Meleagros laticeps sp.n., M. astericollis sp.n., M. setulosus sp.n. и M. pseudosinicola sp.n. — из Вьетнама, Tarsagonum breve sp.n. - из Лаоса и T. indicum sp.n. - из Индии. Для двух последних видов и $T$. kaszabi Louwerens, 1966 установлен новый подрод Louwerensium subg.n. Установлена новая синонимия: Loxocrepis Eschscholtz, 1829 = Violagonum Darlington, 1956, syn.n.

\section{Introduction}

Six new species described in this paper belong to two little-known platynine genera, Meleagros Kirschenhofer, 1999 and Tarsagonum Darlington, 1952, distinctive chiefly in the combination of characteristic body appearance and peculiar tarsi. The former genus was described as a member the tribe Lebiini and then transferred to Platynini and afterwards revised [Morvan, 2004, 2006]. Currently it includes four species from the Himalayas, Indochina, southern China, and Malay Peninsula. Tarsagonum includes two rather dissimilar species from New Guinea or Borneo.
Acronyms used are as follows:

SIEE - the author's reference collection at A.N. Severtsov Institute of Ecology \& Evolution, Russian Academy of Sciences, Moscow;

ZISP - Zoological Institute, Russian Academy of Sciences, St. Petersburg;

ZMMU - Zoological Museum of the Moscow State University.

The following parameters were analyzed: maximum body length measured between apices of closed mandibles and apex of elytra (BL); length of elytron, measured from the highest point of basal ridge to apex (EL); maximum width of elytra (EW); length of gena (= temple) in sagittal plane (GL); width of head across eyes in sagittal plane (HW); width of neck at neck constriction ( $\mathrm{HnW})$; length of eye in sagittal plane (OL); width of pronotum between apical (PA) or basal (PB) angles; length of pronotum along median line (PL); distance between pronotal apex and level of maximum width of pronotum, measured along mid-line (PLw); maximum width of pronotum (PW). Other abbreviations include: DAS - tarsal dorsoapical setae; LAS — tarsal latero-apical setae; US umbilical seta, of USS - umbilical seta series running on elytral interval 9.

Measurements were taken using an eyepiece micrometer, to two decimal places. The means are given in round brackets for the ratios. All labels are printed. Data on labels of type specimens are in quotes.

Male and female genitalia were examined in glycerin, after being boiled for two minutes or put for a day in a diluted $\mathrm{KOH}$ solution and then rinsed.

How to cite this article: Fedorenko D.N. 2020. New species of Meleagros and Tarsagonum (Coleoptera: Carabidae: Platynini) from the Oriental region // Russian Entomol. J. Vol.29. No.2. P.139-147. doi: 10.15298/ rusentj.29.2.03 


\section{Results}

Meleagros Kirschenhofer, 1999

Kirschenhofer, 1999: 68; Morvan, 2004: 3; 2006: 97. — Colpodes: Andrewes, 1923: 683 (part.); Louwerens, 1953: 79 (part.).

Type species: M. coeruleus Kirschenhofer, 1999.

DIAGNOSIS. Macropterous platynine carabids of medium size (BL ca. 10-14 mm); dorsum metallic, violaceous blue; body integuments microscopically setulose to nearly glabrous. Head with a deep neck constriction and one, posterior, supra-ocular seta before the level of posterior margin of eye; eyes small and protruding, genae long, coarsely crossstriated ventrally and laterally. Antennae pubescent from segment 4 onward, scape and pedicel unisetose; antennomere 3 with no setae other than verticellate ones. Right mandible with two large teeth in apical half. Submentum quadrisetose, mentum tooth largely bifid, setae distant. Prosternal process beaded or not, inclination $\mathrm{x}$-shaped. Pronotal and elytral setation complete. Abdominal sternite VII with $1\left(\sigma^{7}\right)$ or $2(+)$ setae on each side. Tarsi wide and flat, tri- or tetracarinate dorsally, with long and very dense yellow ventral vestitute; tarsomeres 1-4 with LAS, metatarsomere 4 lacking LAS, tarsomeres 1-3 with DAS, tarsomere 4 strongly bilobed, anterior lobe longer than posterior, more so in metatarsi; tarsomere 5 glabrous ventrally. Metacoxa bisetose (inner seta missing); setation of pro- and metafemur nearly groundplan for Platynini: profemur with one anterior seta, medioventral, and three posterior setae, basal, medioventral, and apical (medioventral setae ranging slightly in number between species as well as between specimens of one species); metafemur mostly with one or two anteroventral setae. Basal two protarsomeres biserially squamose on ventral side in male. Protibiae anteriorly more or less distinctly micropunctate. Female gonosubcoxite IX with a row of several setae along apical margin, gonocoxite IX with one dorsal seta and 4-5 ventra (lateral) ensiform setae. Aedeagus as for Platynini, internal sac unarmed.

Besides species described below, the genus includes the following four species: M. sikkimensis (Andrewes, 1923) from the Himalayas; M. coeruleus Kirschenhofer, 1999 (Pahang, Malay Peninsula); M. burmanensis Morvan, 2004 (Burma); and M. sinicola Morvan, 2006 (Yunnan, China).

GEOGRAPHIC DISTRIBUTION. Northeastern India, Nepal, Bhutan, Myanmar, Malay Peninsula, southern China, Vietnam.

HABITATS AND HABITS. There are no exact data published except that the adults of $M$. coeruleus have been collected at 1400-1800 m elevation [Kirschenhofer, 1999]. All the adults of the species described below were taken in montane monsoon forests at 1200-2100 m altitudes. That of $M$. astericollis sp.n. was taken by pitfall trap and those of $M$. laticeps sp.n. also by pitfall traps near a fallen tree. The other specimens were hand collected, including a male specimen of M. pseudosinicola sp.n. taken sitting on a Zingiberacea plant leaf in the daytime. These data, combined with macropterous condition of the adults and such morphological adaptations as well-developed prominent eyes and a very dense ventral pubescence of the tarsi, argue in favor of phytophilous, most likely arboricolous, way of life.

COMMENTS. Within Oriental Platynini, Meleagros is distinctive chiefly in the combination of a plesiomorphic character, apically rather a wide, rounded to nearly bifid, mentum tooth, and a few surely apomorphic characters, including peculiar mandibles, one supra-ocular seta, and ventral pad spanning but two (vs. three, as usual in Platynini) basal protar- someres in male. The genus otherwise matches well the lineage formulated by Habu [1978] as the "Loxocrepis subgenusgroup of the genus Agonum Bonelli, 1810" largely corresponding to the genus Loxocrepis Eschscholtz, 1829 sensu lato. Bousquet [2003] recognized also Hikosanoagonum Habu, 1954 as a separate genus, while treating the other members of the lineage as the subgenera of Agonum (sensu lato), among them Gyrochaetostilus Habu, 1978; Lissagonum Habu, 1978; Dicranoncoides Habu, 1978; Nymphagonum Habu, 1978; Celaenagonum Habu, 1978, and Achaetoprothorax Habu, 1978. Schmidt [2017] considered the taxa listed and Takasagoagonum Habu, 1977 as separate genera.

The lineage is defined chiefly by tarsal characters, metatarsomere 4 narrow or very narrow, with outer apical lobe considerably or much longer than inner one and at least outer (anterior) LAS missing. Other distinctive features are as follows: tarsi dorsally bisulcate and mostly carinate between the sulci; setation of the elytra and usually also of the head and pronotum complete (this pattern includes clypeal seta and two supra-ocular setae on each side; pronotum quadrisetose; elytron with parascutellar seta, three discal seta in interval 3, two preapical setae in interval 7, and apical sutural seta); antennae and abdomen without additional setae; abdominal sternite VII with one $\left(\sigma^{7}\right)$ or two $(+)$ setae on each side; profemur mostly with 2-3 posterior medioventral setae; metacoxa mostly trisetose. Many representatives of the genus are macropterous, resulting in metaventrite fairly long, including metepisterna considerably longer than wide and often also elytra mucronate.

Provisionally, I consider those taxa of the lineage that share simple mentum tooth as subgenera or species groups of Loxocrepis, among them Celaenagonum, Takasagoagonum, Gyrochaetostilus, Lissagonum, Dicranoncoides, Nymphagonum, Achaetoprothorax, and Nesiocolpodes Jeannel, 1948. Dicranoncus Chaudoir, 1850 appears to be another subgenus of Loxocrepis, too. These taxa are more or less well delimited when a local fauna is considered [Habu, 1978], but on larger geographic scale the limits between them tend to become increasingly obscure as more species are brought into comparison. No significant character but conspicuously mucronate elytra differentiate Violagonum violaceum (Chaudoir, 1859), the nominotypical species of the genus, from the members of Loxocrepis (s.str.), which invites new synonymy, Loxocrepis Eschscholtz, 1829 = Violagonum Darlington, 1956, syn.n.

Within the lineage, a more or less bifid mentum tooth is observed in Hikosanoagonum and Meleagros only. The two genera share also a short ventral pubescence of the body and wide tarsi, which character combination may suggest closer relationships between them than between either and the other representatives of the lineage in question. Taken separately each or combined, some other features of Meleagros are found also in a few (sub)genera of Loxocrepis. Specifically, Dicranoncus, Gyrochaetostilus, Lissagonum, and Dicranoncoides share multiple (4-7) ventral ensiform setae in the female gonocoxite IX; at least some species of Dicranoncoides, Nymphagonum and Celaenagonum have developed small and prominent eyes and usually also long genae; and Nesiocolpodes has the tarsi quite similar in shape and setation.

Morvan [2004] revised Meleagros and keyed its four species, including an unnamed species from China, he described later [Morvan, 2006] as M. sinicola. He also re-described $M$. coeruleus and M. sikkimensis (Andrewes, 1923) and reported the latter from Katmandu, Nepal, in addition to previously known records of $M$. sikkimensis in India and Bhutan. Two earlier records of this species, 'Pahang' and 'Burma' [Louwerens, 1953] are likely to refer to M. coeruleus and M. burmanen- 
sis Morvan, 2004, respectively. Because the two species are very similar in body shape, including rather narrow pronota and larger (longer) eyes (HnW/OL ca. 1.9), they seem to be more related to each other than to the congeners.

In describing $M$. burmanensis, Morvan distinguished it from $M$. coeruleus by the proximal mandibular tooth absent from (vs. present on) the right mandible, combined with the body more narrow and the pronotum larger, or broader, as indicated in the key. This disagrees with his Figures 2-3 and 13-14 [Morvan, 2004] showing the elytra shorter and the pronotum slenderer in $M$. burmanensis than in M. coeruleus, EL/EW 1.52 vs. 1.62 and PW/PL 1.07 vs. 1.20, respectively. These inconsistency and the fact that I have not seen these species, makes me key them below based on their descriptions and re-descriptions, including illustrations, compared.

\section{Key to SPeCies of Meleagros:}

1(2) Pronotum (Fig. 4) stellate, sides neither explanate nor beaded in front of strongly protruding acute lateral angles; apical angles adherent to neck. Body dorsally and ventrally distinctly setulose. Prosternal process beaded. Eyes small and protruding, HnW/OL 2.4 - Central Vietnam. M. astericollis sp.n.

2(1) Pronotum hexagonal, with lateral angles obtuse to right, sides explanate and/or beaded throughout their length. Body dorsum glabrous or indistinctly setulose.

3(8) Pronotal apical angles more or less distant from neck and a little projecting (Figs 1-2). Prosternal process flat to subconvex, without marginal bead. Eyes small and protruding, HnW/OL 2.3-3.0.

4(5) Body large, BL 12.6-13.8 mm, and glabrous. Eyes very small and protruding, HnW/OL 2.9-3.0. Pronotal basal angles right. Protarsi indistinctly carinate or sulcate Southern Vietnam M. laticeps sp.n.

5(4) Body a little smaller, BL 10.5-11.9 mm. Eyes larger, HnW/OL 2.3-2.5. Pronotal basal angles slightly obtuse. Protarsi finely tetracarinate.

6(7) Elytral intervals very convex. Metafemur unisetose Yunnan, China .................... M. sinicola Morvan, 2006

7(6) Elytral intervals flat or almost so on disc. Metafemur bisetose — Northern Vietnam ................. M. Mseudosinicola sp.n.

8(3) Pronotal apical angles adherent to neck and nearly indistinct. Prosternal process with a marginal bead.

9(10) Body robust due to both head and pronotum wide, $\mathrm{PW} /$ $\mathrm{PL} \approx 1.4$, eyes small and protruding, $\mathrm{HnW} / \mathrm{OL} \approx 2.5, \mathrm{BL}$ 11.5-12 mm. - Southeast India (Sikkim), Nepal, Bhutan M. sikkimensis (Andrewes, 1923)

10(9) Body slender and barely smaller, pronotum and usually head more narrow, PW/PL 1.07-1.24, BL 10-11.6 mm.

11(14) Dorsal microsculpture traceable on at least pronotum. Eyes larger and less protruding, HnW/OL 1.9. Pronotum narrow, PW/PL 1.1-1.2, base wider relative to apex, PB/ PA 1.15-1.25.

12(13) Pronotum with coarse microsculpture ('shagreened'), narrow, $\mathrm{PW} / \mathrm{PL}<1.1$, base a fourth wider than apex...... M. burmanensis Morvan, 2004

13(12) Entire dorsum with superficial microsculpture consisting of transverse meshes; pronotum slightly wider, $\mathrm{PW} / \mathrm{PL} \approx$ $1.2, \mathrm{~PB} / \mathrm{PA} \approx 1.15$...... M. coeruleus Kirschenhofer, 1999

14(11) Head and pronotum without microsculpture, elytral microsculpture isodiametric to barely transverse. Eyes small and protruding, HnW/OL 2.28. Pronotum wider, PW/PL 1.24, with base more narrow, PB/PA 1.08. M. setulosus sp.n.
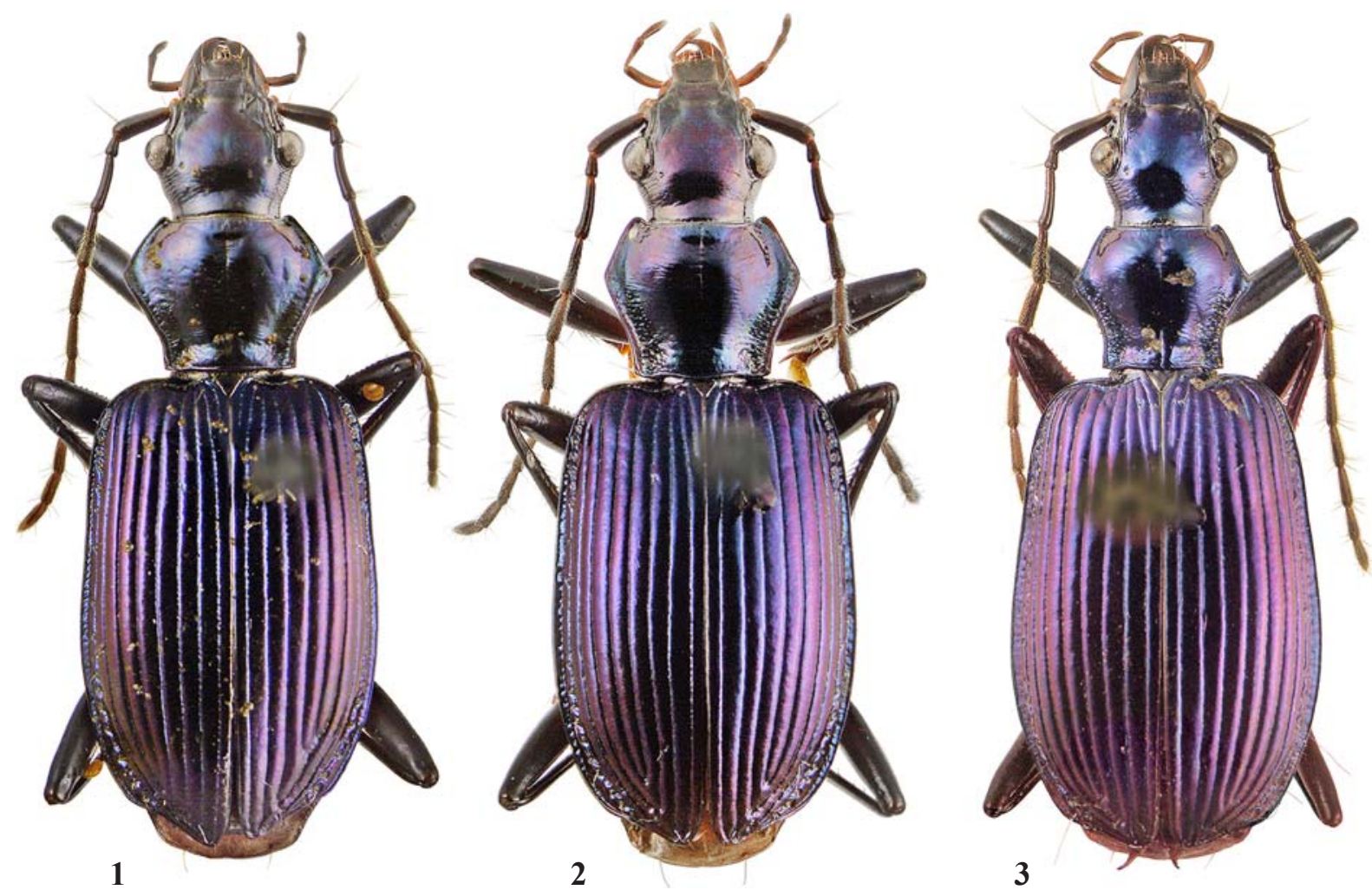

Figs 1-3. Dorsal habitus of holotypes: 1 - Meleagros laticeps sp.n.; 2 - M. pseudosinicola sp.n.; 3 - M. setulosus sp.n. Рис. 1-3. Габитус голотипов, дорзально: 1 - Meleagros laticeps sp.n.; 2 - M. pseudosinicola sp.n.; 3 - M. setulosus sp.n. 


\section{Meleagros laticeps Fedorenko, sp.n.}

Figs 1, 7, 9 .

MATERIAL. Holotype $0^{7}$ (ZMMU): 'S[outh] Vietnam, Lam Dong Prov[ince]., Bi Doup — Nui Ba Nat[ure]. Res[erve]., 12 $07^{\circ}$ N/ 108 $39^{\prime} 44^{\prime \prime}$ E, Bi Doup Mt., N[orthern] slope, $\mathrm{h}=1700-1900 \mathrm{~m}$, 6.V.2009, leg. D. Fedorenko'. Paratypes (SIEE): $\sigma^{7}$, same data, except for 3.V.2009; 19, same data, except for $108^{\circ} 39^{\prime} 20^{\prime \prime}$ E, ..., 16.IV.2008.

DESCRIPTION. BL 12.6-13.8 mm. Body (Fig. 1), including femora and antennal scape, shiny violaceous, tibiae, tarsi and abdominal sternites V-VII black, sternite VII paler apicad; antennae black, with segments 5-11 more or less reddish along edges; trochanters and extreme apices of coxae reddish. Microsculpture obliterate on head and pronotum; isodiametric meshes hardly traceable on frons and vertex. Pronotum with similar yet moderately transverse meshes on sides of disc, with barely more distinct meshes along base, meshes being isodiametric medially to slightly transverse on sides. Elytral microsculpture superficial, consisting of slightly to very transverse meshes. Body glabrous, except for microscopic punctures with almost indistinct cilia hardly traceable on ventrite 3 , metacoxae, and abdominal sternites VII and II-III between metacoxae.

Head large, hexagonal, with neck almost thrice as wide as small protruding eyes, HnW/OL 2.88-2.99 (2.95); genae barely shorter than eyes, GL/OL $0.77-0.84(0.81)$, meeting neck at very obtuse angle; neck constriction distinct yet rather shallow. Supra-ocular seta just before the level of posterior margin of eye, distant rather far from very deep supra-ocular groove. Frontal foveae as round and deep pits behind clypeus, extended into shallow striae diverging to eyes and obliterated behind the level of anterior margin of eye or almost reaching supra-ocular seta. Frons medially smooth (holotype) or with a median impression before eyes (paratypes), which is either deep and transverse () or faint, V-shaped, interrupted medially $\left(O^{\top}\right)$. Genae laterally and ventrally densely cross-striated (plicated). Antennae long filiform, surpassing elytral base by segments 7-11. Labrum symmetric.

Pronotum convex, cordate subhexagonal, PW/PL 1.341.38 (1.36), PW/HW 1.28-1.36 (1.31), broadest almost a fifth from apex, PLw/PL 0.36-0.41 (0.39). Base and apex subtrunctate and subequally wide, PB/PA 1.05-1.11 (1.07); basal and apical angles right, the latter slightly projecting. Sides obtusely angulate, subconvex before, converging and straight to subsinuate behind, parallel in basal fifth. Basal bead entire; apical bead interrupted just medially. Explanate lateral margin fairly wide and slightly reflexed at lateral angle, very narrow before, rather narrow and strongly reflexed behind; lateral bead fine, traceable in front of lateral angle only. Median line thin, moderately deep, obliterate basally and apically. Apical transverse impression barely traceable just medially; basal transverse impression deep wshaped. Very deep basal foveae just outside, reaching to surpassing middle. Basal foveae up to lateral groove and base just inside finely and densely punctate and slightly crossstriated. Disc very finely and rather densely cross-striated.

Elytra subquadrate, EL/EW 1.50-1.56 (1.54), EW/PW 1.41-1.44 (1.43), truncate basally, with humeri rounded, broadest behind middle; sides straight and barely diverging in basal half, rounded behind, each with a slight preapical

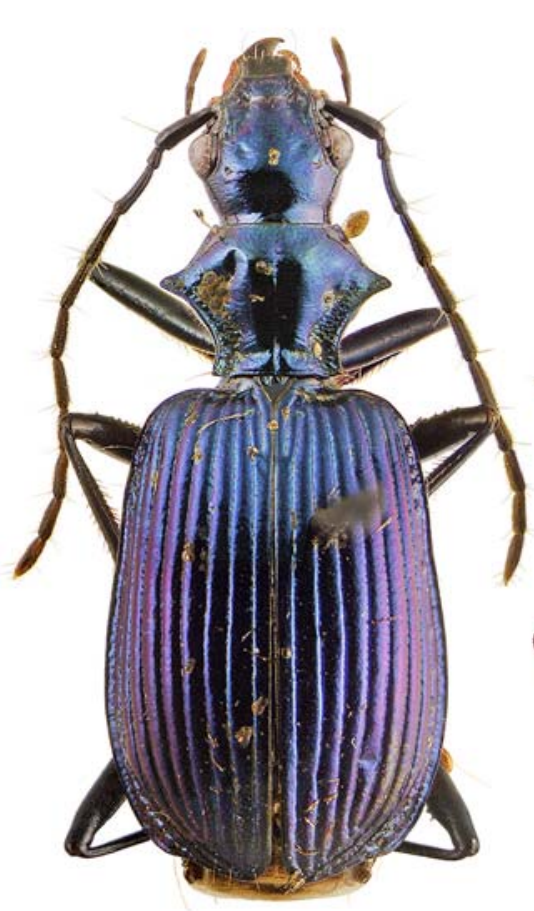

4
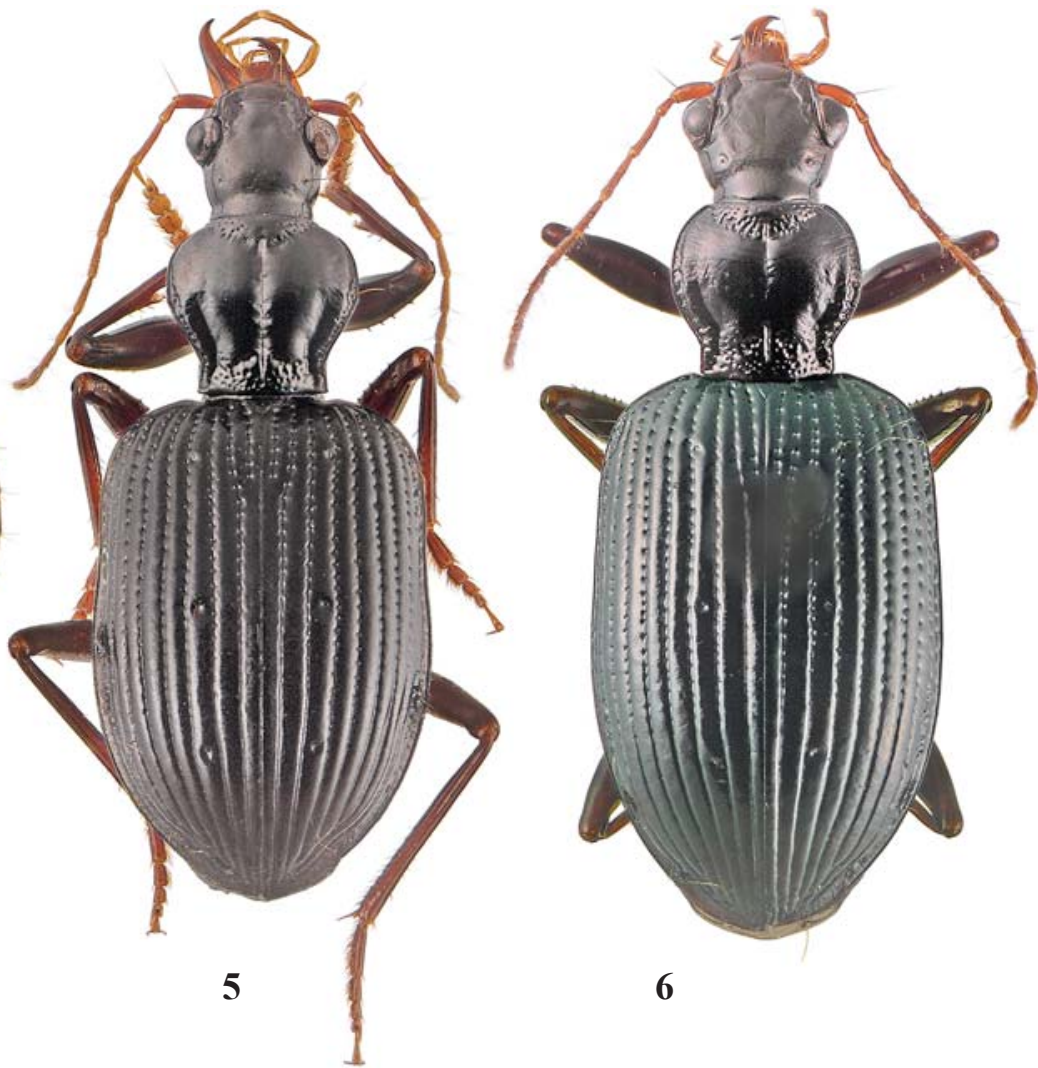

6

Figs 4-6. Dorsal habitus of holotypes: 4 - Meleagros astericollis sp.n.; 5 - Tarsagonum (Louwerensium) breve sp.n.; 6 - T. (L.) indicum sp.n.

Рис. 4-6. Габитус голотипов, дорзально: 4 - Meleagros astericollis sp.n.; 5 - Tarsagonum (Louwerensium) breve sp.n., holotype; $6-T$. (L.) indicum sp.n. 
sinuation; apices separated and blunt. Basal ridge sinuous, with nearly indistinct humeral angle opposite stria 5 . Striae deep, very finely punctate; intervals subconvex on disc, convex basally, apically and laterally; stria 3 adjoining apical bead; stria 8 narrow and costate apically. Discal seta d1 adjoining stria $3, \mathrm{~d} 2$ and $\mathrm{d} 3$ adjoining stria 2; interval 7 bisetose apically (posterior seta in interval 3). USS: 19-21, US sparser in middle third

Underside: Prosternal process flat, not beaded. Sides of metaventrite, metepisterna and base of abdominal sternite I densely punctate; mesepisterna anteriorly with slightly sparser punctures, propleura basally with fine sparser punctures; surface otherwise impunctate.

Legs: pro- and mesotarsi flat and wide in both sexes, distinctly wider than metatarsi; these slightly wider than usual in Platynini, with tarsomeres 1-4 subequally wide; metatarsomeres 1-3 deeply bisulcate-tricarinate; mesotarsomeres 1-3 bisulcate, with fine lateral carinae and blunt median carina; protarsomere 1 without $\left(O^{7}\right)$ or with $(+)$ rather shallow lateral sulci in male, protarsomeres 2-4 with two finest and vague lateral carinae. Profemur with one anterior seta and three posterior setae, with an additional seta near basal one (the additional seta is ventromedial in holotype while basal unilateral in paratypes); metafemur bisetose.

Aedeagus median lobe (Figs 7,9) with apex triangular; internal sac unarmed.

Female gonocoxite with five outer ensiform setae.

DIAGNOSIS. The largest species in the genus, with the head fairly large; body integuments glabrous; pronotal sides subconvex in front of lateral angles ( $v s$. concave to straight); protarsi almost glabrous dorsally in male, and prosternal process not beaded. Meleagros sikkimensis as the most similar species is distinctive from the new species also in the pronotum smaller (PW/HW 1.1, EW/PW 1.7), prosternal process beaded, and USS consisting of 17-18 US only.

NAME. Refers to the head which is rather wide relative to the eye.

GEOGRAPHIC DISTRIBUTION. Only known from the type locality.

\section{Meleagros pseudosinicola Fedorenko, sp.n.} Figs 2, 8, 10.

MATERIAL. Holotype O' (ZISP): 'ВЬETHAM горы, у Ша-па 1600-2000 м, 11.8.1962г. Кабаков' (Vietnam, mountains near Sa Pa, 1600-2000 m, 11.VIII.1962, [O.N.] Kabakov [leg.]). Paratype $\sigma^{7}$ (SIEE) labelled: 'N-Vietnam, $40 \mathrm{~km}$ WNW of Lao Cai, env. Y Ty, Bat Xat N[ational]P[ark], 22 $36^{\prime} 31^{\prime \prime} \mathrm{N} / 103^{\circ} 37^{\prime} 23^{\prime \prime} \mathrm{E}, \mathrm{h}=2000-2100$ m, 4-14.VI.2019, leg. D.Fedorenko',

DESCRIPTION. BL 10.9-11.5 mm. Body (Fig. 2) shiny violaceous blue, femora and scape more or less deep violaceous; tibiae, tarsi, antennomeres 2-4 and abdomen, except for extreme base of sternite II, black; antennae otherwise dark brown, increasingly reddish apicad; mouthparts dark reddishbrown to dark brown; abdominal sternite VII more or less pale along apical margin. Microsculpture obliterate on head and pronotum, with very superficial isodiametric meshes more or less traceable on sides of frons and vertex, and more distinct isodiametric to slightly transverse meshes on sides of pronotal base. Elytral microsculpture superficial, consisting of transverse and rather narrow meshes. Body microscopically punctate and rather densely yet indistinctly ciliate.

Head wide, HnW/OL 2.34-2.48; eyes small and protruding, longer than genae, GL/OL $0.55-0.68$, these meeting neck at very obtuse angle, shallowly cross-striated; neck constriction shallow. Supra-ocular seta on a level with posterior margin of eye, distant rather far from deep supra-ocular groove.
Frontal foveae round and fairly deep behind clypeus, laterally extended into a fine, more (paratype) or less (holotype) distinct, impressed line, with a blunt carina just outside, diverging to eyes and reaching the level of eye midlength. Antennae long filiform, surpassing elytral base by segments $7-11$.

Pronotum convex, cordate subhexagonal, PW/PL 1.261.31, PW/HW 1.26-1.28, broadest a third from apex, PLw/PL $0.33-0.35$. Base and apex almost indistinctly bisinuate and subequally wide, PB/PA 1.06-1.07. Basal angles sharp, slightly obtuse to almost right; apical angles slightly acute and porrect; basal and apical beads entire. Sides obtusely angulate, converging and nearly straight before and behind, sinuate a fourth from base. Explanate lateral margin moderately wide, wide inside lateral angle, strongly reflexed in basal half; lateral bead fine, only traceable anterior to lateral angle. Median line fine, almost reaching base and apex. Basal and apical transverse impression vague. Basal foveae deep and slightly oblong in basal two thirds, with more (holotype) or less (paratype) deep forward extensions running parallel to lateral edge and reaching apical 1/3-1/6; lateral margin outside them and basal foveae densely punctate and somewhat transversely rugulose; explanate lateral margin anteriorly more sparsely punctate to nearly smooth, with punctures confined to lateral groove only. Disc finely transversely rugulose.

Elytra rather square, EL/EW 1.49-1.56, EW/PW 1.551.61 , truncate basally, with humeri widely rounded yet distinct, broadest three fifths from base, straight and barely diverging before, rounded behind, each with a shallow preapical sinuation; apices separated, blunt or rounded. Basal ridge sinuose, with indistinct humeral angle opposite stria 5. Striae deep, very finely punctate in basal fourth, indistinctly punctate behind; intervals subconvex (paratype) to convex (holotype), with at least intervals $1-5$ being nearly flat on disc (deep elytral striae in Fig. 2 create optical illusion of the intervals being much more convex than in fact); interval 3 merging into apical bead, with seta d1 adjoining stria $3, \mathrm{~d} 2$ adjoining stria $2, \mathrm{~d} 3$ near stria 2 (paratype) or left unilateral in the middle of interval (holotype); interval 8 narrow and costate apically. USS: 19-23, US being sparser in middle third; interval 7 bisetose apically (posterior seta in interval 3).

Underside: Prosternal process subconvex, not beaded. Sides of metaventrite, metepisterna and base of abdominal sternite II densely to confluently punctate; mesepisterna anteriorly and propleura basally slightly less so; propleura otherwise very finely and much more sparsely punctate.

Legs: as in M. laticeps sp.n., except that tarsomeres 1-3 are deeply bisulcate-tricarinate on meso- and metatarsi while bisulcate on protarsi, with sharp lateral carinae. Profemur with one anteroventral seta, and three posterior setae (additional unilateral medioventral seta present in paratype); metafemur bisetose (distal, median, seta absent unilaterally from holotype).

Aedeagus median lobe (Figs 8, 10).

DIAGNOSIS. The new species is only different from $M$. sinicola in the elytral intervals being flat ( $v s$. very convex). The other differences are subtle if any. The pronotum is barely wider relative to the head, with maximum width a third (vs. two fifths) from apex, and the metafemur generally bisetose (vs. unisetose). This may suggests subspecies status of the new species or the two names being conspecific. To solve the problem more material is required.

NAME. Refers to great similarity of the new species to $M$. sinicola.

GEOGRAPHIC DISTRIBUTION. Known from the Hoang Lien mountain ridge, northern Vietnam. 


\section{Meleagros setulosus Fedorenko, sp.n.} Fig. 3.

MATERIAL. Holotype + (ZMMU): 'Vietnam, prov[ince]. Ha Tinh, Vu Quang (Phu Quon) [Nature] reserve, h 1.200 m, 526.VIII.1997, leg. M. Kalyakin'.

DESCRIPTION. Similar to $M$. laticeps sp.n. except as follows: BL 11.6 mm. Body (Fig. 3) shiny, bright violaceous, abdomen and legs black, femora with faint violaceous tinge; protrochanters, palps, scape condyle, and antennomeres 511 along edges reddish; abdominal sternite VII yellow in apical third. Head and pronotum without microsculpture; elytral microsculpture very superficial, consisting of barely transverse to isodiametric meshes. Underside, coxae, trochanters and femoral bases, rather densely ciliate; dorsal pilosity extremely short and very sparse, just traceable along sides of both vertex and pronotum (mostly in basal half) and on elytral disc, more distinct along sides toward elytral apices.

Head smaller, HnW/OL 2.28, genae two thirds as long as eyes, GL/OL 0.65. Frontal foveae posteriorly extended into very shallow striae reaching the level of eye midlength. Frons medially smooth. Labrum slightly asymmetric, with right angle subacute and slightly in advance of rectangular left angle.

Pronotum smaller, PW/PL 1.24, PW/HW 1.23, PLw/PL 0.39 , PB/PA 1.08; base barely convex, slightly sinuate at a distance from pointed right basal angles; apex barely sinuate. Sides sinuate just before slightly obtuse lateral angles, evenly sinuate behind, slightly diverging in basal fifth, with a vague blunt tooth just behind lateral angle. Apical angles adherent to neck, right, with extreme tips only projecting. Basal bead obsolete just medially. Explanate lateral margin slightly less wide, behind lateral angle in form of a slightly broadened lateral bead. Median line deep, reaching base and almost reaching apex. Basal transverse impression transverse, interrupted medially. Forward extensions of basal foveae disappearing two thirds from base. Sides, including basal foveae, lateral groove and base just inside, finely and densely punctate and slightly cross-striated in basal two thirds.

Elytra oval, broadest three fifths from base, nearly semicircular behind, EL/EW 1.50, EW/PW 1.73, with preapical sinuation less oblique and apices rather widely rounded. Striae slightly deeper, crenulate rather than punctate; intervals very convex laterally and apically; interval 8 almost carinate apically. USS: 19-20.

Underside: Prosternal process impressed inside a Ushaped marginal bead.

Legs: tarsi flat and wide, pro- and mesotarsi barely wider than metatarsi; protarsi finely tetracarinate due to median carina wide and deeply grooved; median carina broadened slightly apicad and faintly grooved on mesotarsomeres 1-4; metatarsomeres 1-4 tricarinate. Profemur with 1+2 anterior setae and $1+2$ posterior medioventral setae.

Female gonocoxite with 4-5 ventral ensiform setae.

DIAGNOSIS. The new species is very similar to $M$. coeruleus in many points, including body shape and proportions. Both share distinctly setulose ventral body integuments, moderately large head, tetracarinate protarsi, small pronotum, with explanate lateral margin almost reduced to the lateral bead, and a very slightly asymmetric labrum. Differences only include about isodiametric elytral microsculpture ( $v s$. transverse in that species) and US being hardly more in number, 19-20 vs. 17-18. Morvan's illustrations [Morvan, 2004: Figs 3 and 26] shows also that the female paratype of $M$. coeruleus has the eyes a bit larger, more than half as long as the neck wide, and the mentum tooth rounded apically (vs. bifid, with apical teeth rounded), but the latter difference may have come from individual variability.

NAME. Refers to the ventrally setulose body.

GEOGRAPHIC DISTRIBUTION. Known from the type locality only.

\section{Meleagros astericollis Fedorenko, sp.n.}

Fig. 4.

MATERIAL. Holotype $q$ (ZMMU): 'Vietnam, Dak Lak Prov[ince]., Chu Yang Sin Nat[io]n[al]. Park, $12^{\circ} 22^{\prime} 40^{\prime \prime} \mathrm{N} /$ $108^{\circ} 21^{\prime} 11^{\prime \prime} \mathrm{E}, 1.5 \mathrm{~km} \mathrm{~W}$ [of ] Chu Pan Phan Mt, h=1650 m, 30.III10.IV.2012, A.Abramov leg.'

DESCRIPTION. Similar to M. setulosus sp.n. except as follows: BL 10.7 mm. Body (Fig. 4). Microsculpture obliterate on head, with isodiametric meshes hardly traceable on vertex but medially; consisting of slightly transverse and highly superficial meshes on pronotum. Body, including proand metafemora ventrally, rather densely setulose; this erect and short pilosity is very distinct on genae and along sides of pronotum.

Head: HnW/OL 2.50, genae three fourths as long as eyes, GL/OL 0.75 . Frontal foveae extended slightly to eyes. Vertex with a pair of shallow round pits between eyes.

Pronotum wide due to acute and very prominent lateral angles, PW/PL 1.55, PW/HW 1.42, PLw/PL 0.39, PB/PA 1.12. Sides sinuate just in front of lateral angles, deeply sinuate behind, and distinctly diverging in basal fifth toward acute and pointed basal angles; apical angles obtuse, with extreme tips barely projecting. Disc very convex, without lateral bead or explanate lateral margin in front of lateral angle. Basal transverse impression interrupted just medially. Basal foveae very deep basally, then extended parallel to lateral edge nearly to the level of lateral angles. Explanate, slightly reflexed and densely to confluently punctate areas outside the extensions of basal foveae substituted for explanate lateral margins; this latter reduced to a fine lateral bead. Propleura tumid, in dorsal view just traceable between lateral and basal angles.

Elytra: EL/EW 1.42, EW/PW 1.48, with sides barely concave a third from base. Striae very finely punctate; intervals vaguely punctulate (where setulose). USS: 20-21.

Legs: protarsus 4-carinate, lateral carinae fine, median ones faint. Profemur with one anterior seta, 2-3 setae additional and proximal to posterior medioventral seta and one seta unilaterally additional to posterobasal seta.

Female gonocoxite with four ventral ensiform setae.

DIAGNOSIS. The species is very distinctive in having the setulose body and stellate pronotum without explanate lateral margin or lateral bead anterior to acute and strongly projecting lateral angles.

NAME. Refers to the stellate shape of the pronotum.

GEOGRAPHIC DISTRIBUTION. The type locality only.

Tarsagonum Darlington, 1952

Darlington, 1952: 114, 120; Louwerens, 1966: 36.

Type species: Tarsagonum latipes Darlington, 1952.

DIAGNOSIS. Macropterous, small- to medium-sized (BL 7-11 mm) platynines; body glabrous, black, with mouthparts, antennae and tarsi more or less pale. Head with neck constriction, genae well-developed. Submentum quadrisetose; mentum tooth simple, pointed and more or less sulcate longitudinally, setae very distant. Prosternal process with a thick marginal bead, inclination costate to carinate. Pronotum cordate and rather small. Elytra wide, subquadrate, without basal ridge (at least inside stria 5). Tibiae deeply grooved externally. Tarsi wide, flat, bisulcate, with meso- and meta- 
tarsi tricarinate, and asymmetric: tarsomeres 1-3 parallelsided, in posterior part considerably wider than in anterior (relative to longitudinal axis), tarsomere 4 with anterior lobe as long as the tarsomere proper and posterior lobe indistinct. Body setation as for Meleagros, except as follows: two supraocular setae on each side, with posterior seta inserted distinctly behind the level of posterior margin of eye; posterolateral pronotal seta present or not; elytral discal setae not adjoining striae, apical sutural seta missing; profemur glabrous anteriorly, with three posterior setae; metafemur with one anteroventral seta, median. Basal three protarsomeres with ventral pad in male.

GEOGRAPHIC DISTRIBUTION. New Guinea, Borneo, Laos, Southern India.

HABITATS AND HABITS. Collecting circumstances of T. latipes [Darlington, 1952] and the fact that morphological adaptations are similar in Meleagros and Tarsagonum suggest arboricolous way of life of the adults of the latter genus.

COMMENTS. The genus includes four species hitherto known from very few localities in the Papuan and Oriental regions. Two earlier described species are strictly insular and southern in distribution, and discovery of further two species in mainland South and Southeast Asia extends the genus range much northwards and westwards.

Many features, including such synapotypic characters as tarsal shape and setation, elytral basal ridge obliterate and discal setigerous pores isolated from the striae, seem to support well monophyly of the genus. On the other hand, differences between the Papuan and Oriental species are sufficient to erect a new subgenus for the latter.

\section{Subgenus Louwerensium Fedorenko, subg.n.}

Type species: Tarsagonum kaszabi Louwerens, 1966.

DIAGNOSIS. As compared with Tarsagonum (s.str.): Body barely smaller, BL 7-9 (vs.10-11) mm. Head with neck constriction deep ( $v s$. slight), eyes small and protruding ( $v s$. medium-sized and moderately convex), genae long, slightly oblique, with a distinct re-entrant angle between them and eyes ( vs. genae very oblique, combined with a continuous eye-togena outline); posterior supra-ocular seta inserted much behind the level of posterior margin of eye. Pronotum strongly cordate, very convex, with posterolateral seta missing and apical angles adherent to neck, coarsely punctate basally and apically; sides deeply sinuate in front of basal angles, without explanate lateral margin; basal foveae very deep and very long (vs. pronotum rather flat, quadrisetose, with apical angles distant from neck, finely and confluently punctate except medially and medio-apically; sides slightly sinuate basally, lateral margin explanate, basal foveae shallow). Elytra truncate apically (vs. mucronate, with a long spine opposite stria 3 ), striae very deep and coarsely punctate (vs. moderately deep and very finely punctate), intervals convex or very so (vs. flat); interval 3 with three discal setae ( $v s$. with two, $\mathrm{d} 3$ missing), $\mathrm{d} 1$ near stria3, $\mathrm{d} 2$ and $\mathrm{d} 3$ subequally distant from stria 2 and 3 . Metaventrite with two small and very deep median pits, anterior on a level with hind margin of mesocoxae, posterior in intersection of discremen and katepisternal suture. Propleura along basal flange and mesopleura sparsely and coarsely punctate, metepisterna and sides of metaventrite very sparsely punctate ( $v s$. ventral side finely and densely punctate, but mesoventrite and metaventrite medially, abdominal sternites IV-VII, and median part of sternite III impunctate).

The subgenus includes two species from Southern India or Indochina.

NAME. Neuter, given after C.J. Louwerens (Hilversum, the Netherlands), a well-known specialist in the Oriental, mostly Malayan, Carabidae, especially Platynini. He described T. kaszabi and specified many significant differences between his species and T. latipes.

COMMENTS. Darlington [1952] did not describe USS pattern for Tarsagonum, and Lowerens [1966] mentioned almost continuous USS in T. kaszabi. Both here described species have USS divided into two widely separated groups, posthumeral (6 US) and postmedian (8 US), which character is far advanced in contrast with continuous USS.

\section{Tarsagonum (Louwerensium) breve Fedorenko, sp.n.}

Figs 5, 11-13.

MATERIAL. Holotype $O^{7}$ (ZMMU): 'Central Laos, near Vang Vieng vill., 18-22.VIII.2005, leg. A.Sokolov'.

DESCRIPTION. BL $9 \mathrm{~mm}$. Body (Fig. 5) black, a little shiny, legs rather dark brown, with knee and tibiae toward apices slightly reddish; antennae, tarsi and mouthparts rather pale reddish brown, mandibles toward apices and antennal scape slightly infuscated. Microsculpture distinct, rather coarse, consisting of isodiametric meshes on head, superficial at middle of both clypeus and neck, obliterate on sides of clypeus and neck; pronotal and elytral microsculpture more superficial. consisting of small, moderately or very transverse meshes, respectively.

Head: Eyes hemispherical, small, protruding, and dorsolateral owing to supra-ocular groove being very deep and posteriorly reaching posterior margin of eye; genae long, GL/ OL 0.88 , very slightly oblique, nearly straight behind eyes, increasingly convex toward and meeting neck at obtuse angle; neck constriction deep laterally, more shallow medially. Frontal foveae sulciform, s-shaped, fairly deep and long, barely surpassing the level of anterior supra-ocular seta; posterior seta closer to neck constriction than to eye. Frons between eyes with a shallow round pit.

Pronotum barely wider than long, PW/PL 1.08, a fourth wider than head, PW/HW 1.25, broadest two fifths from apex PLw/PL 0.42; base slightly convex and slightly broader than truncate apex, PB/PA 1.15. Sides very convex in apical half, indistinctly angulate at lateral seta, converging and straight behind, slightly diverging in basal fourth. Basal angles right and pointed, apical angles adherent to neck, very obtuse but a minute blunt tooth. Lateral bead conspicuous, fine, very so apically; lateral groove narrow, deep and uneven in basal two thirds; basal bead missing; apical bead well-developed at apical angles only, otherwise obliterate. Median line very deep and crenulate, reaching base, obliterate apically. Basal and apical transverse impressions deep, the latter interrupted just medially. Basal foveae reaching the level of lateral setae, almost reaching basal margin, diverging on each side of basal transverse impression. Disc smooth, base posterior to basal transverse impression, apex in front of and including apical transverse impression, and lateral groove except apically coarsely and more or less densely punctate to somewhat rugose-punctate.

Elytra short and wide, EL/EW 1.43, EW/PW 1.78, nearly parallel-sided, broadest just behind middle, rounded apically combined, with extreme tips blunt, no preapical sinuation; humeri square yet widely rounded; sides slightly concave a third from base. Basal ridge obliterate inside stria 5 (inside stria 4 in dorsal view). Striae coarsely punctate in basal third, smooth behind.

Underside: prosternal process rather short, with entire marginal bead; its apex rounded in lateral view, except for a minute tubercle at tip; inclination carinate in posterolateral view. 
Legs: Profemur without postero-apical seta, metatrochanteral seta present.

Aedeagus (Figs 11-13): median lobe in ventral view rather narrow apically, with right margin concave preapically. Internal sac with two dorsolateral teeth, right tooth median, very large and long, left one preapical and rather small.

DIAGNOSIS. The species is distinctive chiefly in having short subquadrate elytra and the head square owing to nearly parallel-sided genae, with the eyes small and very convex. Aedeagus is distinctive, too.

NAME. Refers to a robust habitus of the species, including short elytra.

GEOGRAPHIC DISTRIBUTION. Known from the type locality only, Vientiane Province, Laos.
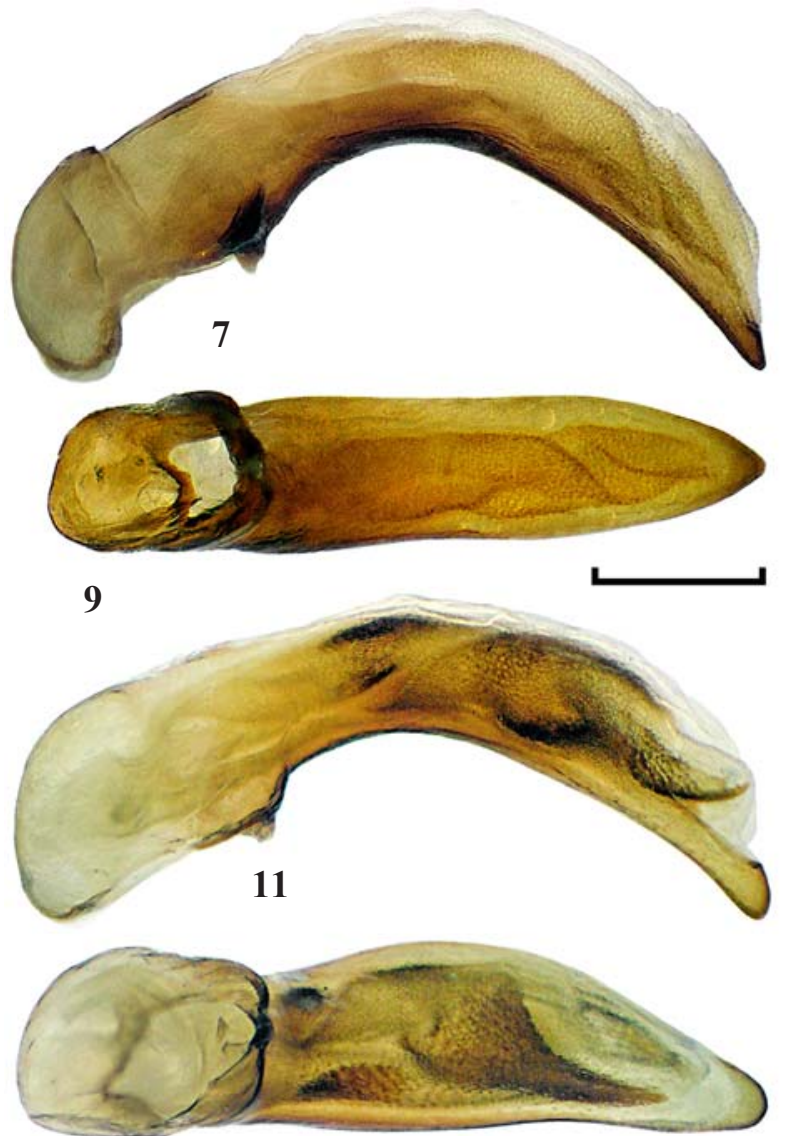

13

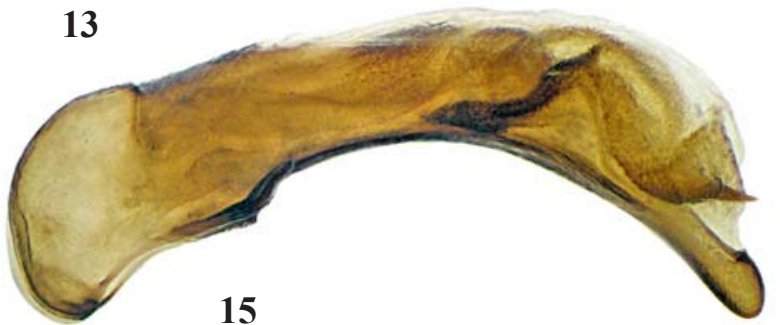

15
Tarsagonum (Louwerensium) indicum

Fedorenko, sp.n.

Figs 6, 14-16.

MATERIAL. Holotype $\sigma^{7}$ (ZMMU) and paratypes, $\sigma^{7} q$ (SIEE), labelled: 'S-India, Karnataka, W[estern]. Ghats, Shimoga Distr., Jog Falls, $14^{\circ} 13.32^{\prime} \mathrm{N} / 74^{\circ} 48.6^{\prime} \mathrm{E}, \mathrm{h}=505 \mathrm{~m}, 30 . \mathrm{X} .2013$, leg. S.Saluk'.

DESCRIPTION. As for the previous species, except as follows: BL 8.6-9.1 mm. Body (Fig. 6). Microsculpture absent from clypeus; elytral microsculpture consisting of moderately transverse to isodiametric meshes.

Head hexagonal, eyes slightly larger and less convex, hemispherical, supra-ocular grooves slightly more shallow, genae subconvex, GL/OL 0.58-0.67 (0.63), and more oblique. Frons between eyes flat to transversely concave.

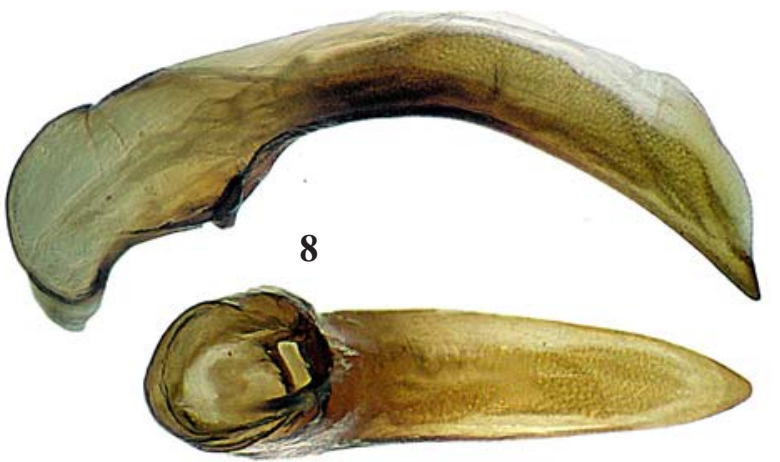

10
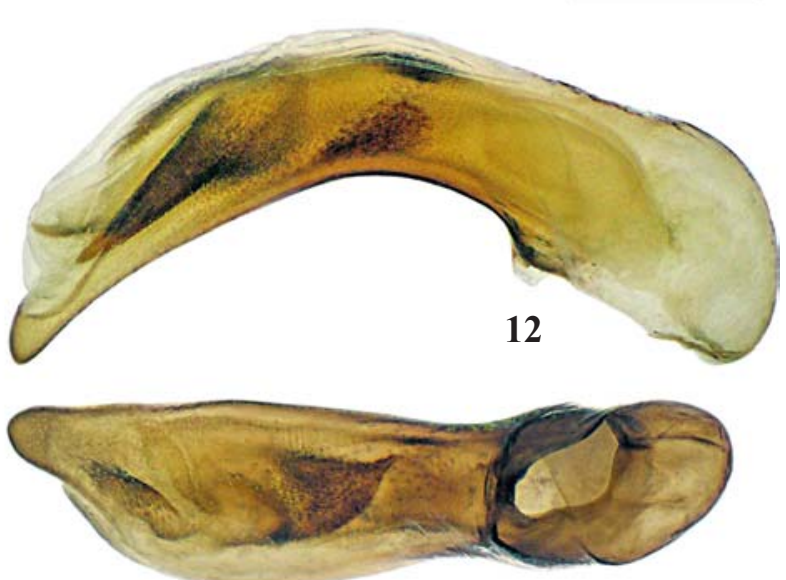

14

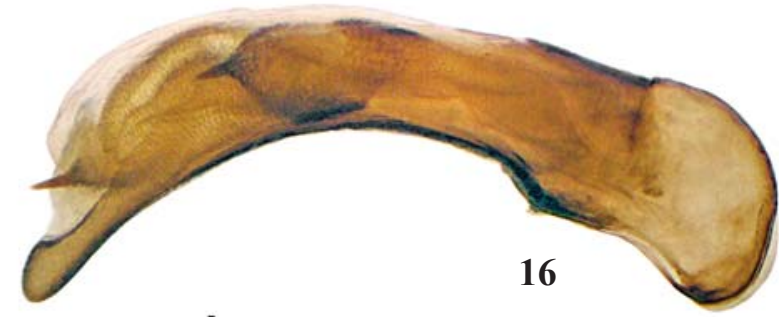

Figs 7-16. Median lobe of aedeagus in holotypes: 7, 9 - Meleagros laticeps sp.n.; 8, $10-$ M. pseudosinicola sp.n.; 11-13 Tarsagonum (Louwerensium) breve sp.n.; 14-16 - T. (L.) indicum sp.n.; 7, 8, 11, 15 - left aspect; 9-10, 13-14 — ventral aspect; 12 , 16 - right aspect. Scale bars: $0.5 \mathrm{~mm}$

Рис. 7-16. Средняя доля эдеагуса голотипов: 7, 9-Meleagros laticeps sp.n.; 8, 10-M.pseudosinicola sp.n.; 11-13 — Tarsagonum (Louwerensium) breve sp.n.; 14-16 - T. (L.) indicum sp.n.; 7, 8, 11, 15 — слева; 9-10, 13-14 - вентрально; 12, 16 — справа. Масштаб: $0,5 \mathrm{~mm}$. 
Pronotum similar except that apical angles are distinct, extreme apices of basal angles blunt, lateral bead subequally fine all along, and basal foveae barely longer; PW/PL 1.091.15 (1.11), PW/HW 1.14-1.17 (1.15), PLw/PL 0.41-0.48 (0.45), PB/PA 1.17-1.18 (1.17).

Elytra longer, EL/EW 1.48-1.57 (1.52), EW/PW 1.821.90 (1.85); sides straight to indistinctly concave in basal half.

Underside: prosternal process long, triangular in ventral view, with marginal bead reduced to two, parallel, lateral sections; apex in lateral slightly acute to right; inclination costate to sub carinate in posterolateral view, concave in lateral view.

Legs: Profemur with postero-apical seta and often also posterobasal seta vestigial, short; metatrochanteral seta missing.

Aedeagus (Figs. 14-16): median lobe in ventral view wide apically, with right margin straight preapically. Internal sac similar, except that right tooth is smaller and short.

Female gonosubcoxite IX with multiple setae (more than a dozen) along apical margin, these being straight and arranged into a row externally while slightly curved and clustered inside; gonocoxite IX triangular yet narrow, parallelsided in apical half and widely rounded apically, with a preapical nematiform seta and two small ventral setae, dorsal seta missing.

DIAGNOSIS. The new species is very similar to $T$. (L.) breve sp.n. For differences see the description above. The third member species of the genus, Tarsagonum kaszabi was described based on a single female specimen from Borneo. It is distinguished from the other two in the body smaller, BL 7 $\mathrm{mm}$, the eyes sinuate anterolaterally, the elytral striae impunctate in apical two thirds, and USS nearly continuous.

NAME. Toponymic, refers to the type locality of the species.

GEOGRAPHIC DISTRIBUTION. Known from the type locality only.

Acknowledgements. I am much obliged to Dr. Boris Kataev (ZISP) for the loan of material under his care and also to Dr. Sergey Saluk (Minsk) and Mr. Alexander Sokolov (Moscow) for donating specimens. This study was funded by the Presidium of the Russian academy of sciences, Program No.41 "Biodiversity of natural systems and biological resources of Russia

\section{References}

Andrewes H.E. 1923. Papers on Oriental Carabidae. - XII // Ann. Mag. Nat. Hist. Ser.9. Vol.12. P.679-690.

Bousquet Y. 2003. Platynini // I. Löbl, A. Smetana (eds.). Catalogue of Palearctic Coleoptera. Vol.1. Archostemata - Myxophaga Adephaga. Stenstrup: Appolo Books. P.449-469.

Chaudoir M. 1850. Mémoire sur la famille des Carabiques // Bull. Soc. Nat. Moscou. T.23. No.2. P.367-478.

Darlington P.J., jr. 1952. The carabid beetles of New Guinea. Pt.2. The Agonini // Bull. Mus. Compar. Zool. Harvard. Vol.107. No.3. P.87-252. 4 pls.

Darlington P.J., jr. 1956. Australian carabid beetles III. Notes on the Agonini // Psyche. Vol.63. No.1. P.1-10.

Eschscholtz J.F. 1829. Zoologischer Atlas, enthaltend Abbildungen und Beschreibungen neuer Thierarten, wahrend des Flottcapitains von Kotzebue zweiter Reise um die Welt, auf der RussischKaiserlichen Kriegsschlupp Predpriaetie in den Jahren 18231826 beobachtet. Lief.1. Berlin: G. Reimer. I-IV + 17 S + 4 Pls.

Habu A. 1954. Descriptions of some new carabid-beetles (Coleoptera) from Japan // Bull. Nation. Inst. Agric. Sci. Ser.C. Vol.4. P.281-294.

Habu A. 1977. Takasagonum scotus, gen. nov. and sp. nov. (Platynini) from Formosa (Coleoptera, Carabidae) // Ent. Rev. Japan. Vol.30. Nos1-2. P.1-5.

Habu A. 1978. Fauna Japonica. Carabidae. Platynini (Insecta: Coleoptera). Keigaku Publishing Co., Tokyo, Japan. I-VIII + 447 pp. + $26 \mathrm{Pl}$.

Kirschenhofer E. 1999. Über neue und wenig bekannte Carabiden Arten und Gattungen aus Südeuropa, Kleinasien, Süd- und Südostasien (Coleoptera: Carabidae: Lebiinae) // Ann. Hist.Nat. Mus. Nat. Hung. Bd.91. S.67-79.

Louwerens C.J. 1953. The Oriental species of Colpodes Macl. (Col. Carabidae) // Treubia. Vol.22. Pt.1. P.75-151.

Louwerens C.J. 1966. Some more Malayan Carabidae in the Stockholm Museum of Natural History // Entomol Tijdschr. Årg.87. H.1 P.33-39.

Morvan D. mab. 2004. Nouvelle tribu et nouvelles espèces de Platyninae. Nouvelles espèces de Tiruka et Sphodrini de la région orientale, Asia // Loened Aziad Amprevaned Feuraskelleged C'hwiledig. Vol.9. P.1-65.

Morvan D. mab. 2006. Nouvelles espèces de Platynini et Meleagrosini de Chine. Nouvelles méridion (Coleoptera, Caraboidea, Platyninae) // Bull. Soc. Ent. France. Vol.111. No.1. P.73-99.

Schmidt J. 2017. Platynini // I. Löbl, A. Smetana (eds.). Catalogue of Palearctic Coleoptera. Revised and updated edition. Vol.1. Archostemata - Myxophaga - Adephaga. Leyden-Boston: Brill. P.642-675. 